\title{
A short history of heme dioxygenases: rise, fall and rise again
}

\author{
Emma L. Raven ${ }^{1}$
}

Received: 12 September 2016 / Accepted: 10 November 2016/ Published online: 1 December 2016

(C) The Author(s) 2016. This article is published with open access at Springerlink.com

\begin{abstract}
It is well established that there are two different classes of enzymes - tryptophan 2,3-dioxygenase (TDO) and indoleamine 2,3-dioxygenase (IDO) - that catalyse the $\mathrm{O}_{2}$-dependent oxidation of L-tryptophan to $\mathrm{N}$-formylkynurenine. But it was not always so. This perspective presents a short history of the early TDO and IDO literature, the people that were involved in creating it, and the legacy that this left for the future.
\end{abstract}

\section{Power to the people}

There are fashions in science, just as there are in styles of trousers. Fashions in science are influenced by variables large and small: governments that can control the political climate; policy and funding streams; universities and other institutions that control scientific appointments; geography that can enhance or restrict access to ideas or technology; and the rate of development of technology itself which can either slow down or suddenly speed up scientific progress. But more often than not, fashions in science are also influenced to a greater or lesser extent by people, for it is the people who create the focus, the scientific stimulus, and the new ideas upon which future progress must be based.

In the case of the heme dioxygenase enzymes, a handful of people were highly influential and they laid the foundations for the development of the area over the next 60 years. This short perspective summarises these and other early contributions to the heme dioxygenase field.

Emma L. Raven

emma.raven@le.ac.uk

1 Department of Chemistry, University of Leicester, University Road, Leicester LE1 7RH, UK

\section{In the beginning there were two}

As often happens, two people drew more or less the same conclusions at more or less the same time. In 1955, Mason [1] and Hayaishi $[2,3]$ independently proposed that enzymatic incorporation of molecular oxygen into a substrate was possible. At the time, this was an almost unthinkable idea-probably because the prominent German chemist and Nobel Prize winner Heinrich Wieland (and naturally, therefore, almost everybody else) had ruled the possibility out—but this did not stop Mason and Hayaishi thinking about it quite a lot.

Mason's experiment was published in 1955 [4] and led to his now famous classification of enzymatic oxygen metabolism [5]. Mason proposed that two atoms of molecular oxygen can be incorporated into the substrate and he termed this type of activity an "oxygen transferase". Hayaishi, using mass spectrometry, demonstrated quantitative incorporation of ${ }^{18} \mathrm{O}_{2}$ (and, importantly, not $\mathrm{H}_{2}^{18} \mathrm{O}$ ) into the substrate in the pyrocatechase reaction [6]. He too referred to the activity as "oxygen transferase". Hayaishi, Fig. 1, later introduced the term "oxygenase" to the literature [7], a proposal that had first been mooted at an ACS meeting in 1956 [8] and which has stuck in the heme literature ever since.

\section{Where there's muck there's brass}

Hayaishi's introduction to tryptophan metabolism had occurred from a chance encounter at Osaka University with Kotake. Kotake had devoted much of his life's work to the biochemistry of that particular amino acid in animals and had published some of the earliest seminal studies in the 1930s [9, 10], Fig. 2. Japan at that time was in the 


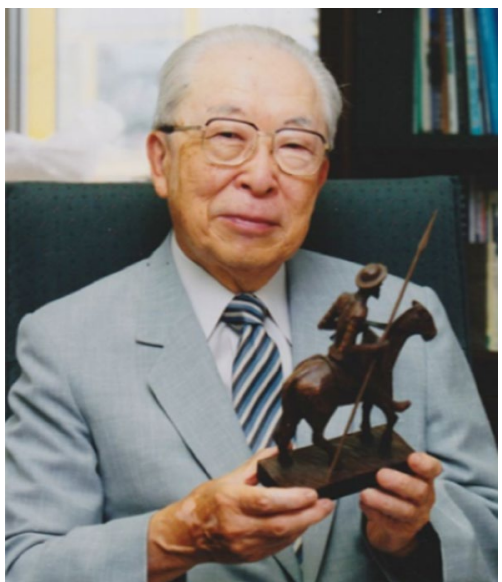

Fig. 1 Professor Hayaishi pictured holding a model of the fictional hero Don Quixote, of whom he was a long-standing admirer (see [113]). The photograph was provided by Hayaishi's daughter, via his former secretary, to Prof. Masao Ikeda Saito

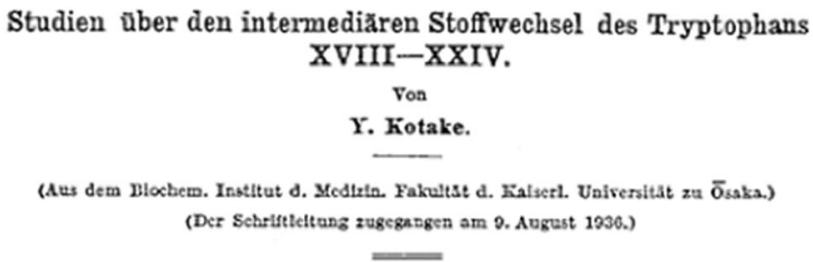

XVIII. Ubber den Mechanismus der Kynurenin-bildung aus Tryptophan. (I. Mitteilung.)

von

Y. Kotake und T. Masayama.

(Unter Mitwirkung von Ch. Itagaki.)

Fig. 2 One of the seminal (but for some readers somewhat impenetrable) papers from Kotake [10]

aftermath of the war, and Osaka had been totally demolished. Kotake, perhaps wishing to see the tradition of a Japanese effort in the tryptophan area continued into the future, donated several grams of the precious compound to Hayaishi. With no chemicals, no equipment to speak of, a non-existent consumables bud get, no animals and probably no students either, Hayaishi has pointed out [2] that his options were somewhat limited. By necessity, he went outside and, literally, dug up some muck and mixed it with his compound. From there he was able to demonstrate that certain microorganisms in soil can grow using tryptophan, and what followed was a series of four consecutive papers all looking at enzymatic incorporation of $\mathrm{O}_{2}$ into a substrate [7, 11-13]. One of these, Fig. 3 [11], concerned itself with the oxidation of tryptophan and examined the conversion of tryptophan to $\mathrm{N}$-formylkynurenine (NFK) in Pseudomonas extracts using mass spectrometry, Scheme 1 . It was the first demonstration that "...both atoms of oxygen incorporated

\section{STUDIES ON OXYGENASES}

ENZYMATIC FORMATION OF KYNURENINE FROM TRYPTOPHAN*

BY OSAMU HAYAISHI, SIMON ROTHBERG, $\dagger$ ALAN H. MEHLER, AND YOSHITAKA SAITO $\$$

From the National Institute of Arthritis and Metabolic Diseases and the National Heart Institule, National Institutes of Health, United States Public Health Service, Bethesda, Maryland)

(Received for publication, July 18, 1957)

Fig. 3 Hayaishi's seminal paper [11] reporting that both atoms of oxygen incorporated into the product during tryptophan oxidation are derived from ${ }^{18} \mathrm{O}_{2}$. Reproduced with permission from The American Society for Biochemistry and Molecular Biology

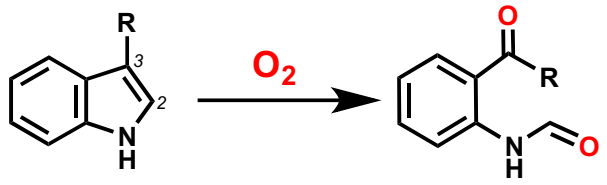

Scheme 1 The oxidation of tryptophan to NFK, as catalysed by IDO and TDO

in the oxidative step are derived from oxygen gas but not from water" [11].

At that time, the metabolism of tryptophan was just beginning to be clarified, and several people-including the distinguished A. Neuberger from Mill Hill in London ${ }^{1}[14$, 15] - had come to the conclusion that NFK was part of the process. But the enzyme responsible for the activity had not been fully established, and it had been temporarily denominated as a "tryptophan peroxidase". The early nomenclature, to put it mildly, would send shivers down the spine of an IUPAC committee. A list of terms as long as the Royal Mile appeared in print: tryptophan pyrrolase (which still pervades in the literature), tryptophan peroxidase, tryptophan oxidase, tryptophan peroxidase-oxidase, and tryptophan oxygenase were all used (see for example [14, 1622]). Most authors evidently found the process of deciding between these terms to be an impossible task and so used them all at the same time. It was Hayaishi himself who brought some order to the confusion, by suggesting in 1970 [23] that the enzyme would most sensibly be named tryptophan 2,3-dioxygenase (TDO), to distinguish its reactivity from any other enzymatic tryptophan activity (e.g. in the formation of tryptophan 5-monooxygenase). Even so, it took some years before the literature adjusted to this brave new world in which one enzyme had only one name.

It had been known at this time that there were other enzymes from different sources capable of catalysing the

\footnotetext{
${ }^{1}$ Fred Sanger was Neuberger's first Ph.D. student.
} 
same reaction as TDO, but with much less substrate specificity than TDO. As far back as 1967, Hayaishi had identified one such enzyme from rabbit intestine [17] and it was initially identified as "tryptophan pyrrolase (tryptophan 2,3-dioxygenase)". In view of the broad substrate specificity of these other enzymes, it was suggested [24], again by Hayaishi, that they be designated as indoleamine 2,3-dioxygenases (IDO), to differentiate them from the TDOs (which are specific for tryptophan) and to convey the message that other substituted indoles were also accessible by these enzymes. Although even as late as 1974 the community was still afflicted by chronic indecision on the names for their pet enzymes, as the early proposal [24] also suggested the very awkward and certainly confusing "indoleamine 2,3-dioxygenase (pyrrolase)" nomenclature. But by the end of the 1970s the literature was more consistent, with regular papers describing the properties of the now easily recognisable indoleamine 2,3-dioxygenase enzyme (see for example [25-34]).

In the intervening years, a much clearer picture has emerged. It is now well known that the IDOs and the TDOs, whilst catalysing the same reaction, have slightly different properties. IDOs are monomeric, while the TDOs are tetrameric. IDOs have wide substrate specificity and will oxidise a range of indoleamine derivatives, while the TDOs are much more discriminating and typically oxidise only L-Trp at any respectable catalytic rate. Also, while IDO is widely distributed in all tissues but not the liver, TDO has most often been cited as being found only in the liver (although there is emerging evidence that it is also located in some cancer cells [35]).

\section{The 1970s: the emergence of heavy metal}

The idea that there could be a role for a metal in tryptophan oxidation took a while to sink in. The earliest mention of a heme dependency that this author was able to identify came in 1959 (and there were indications even earlier than that [36]). Tanaka and Knox [16] presented UV-visible spectra for the TDO from rabbit liver, Fig. 4, with Soret bands that are surprisingly close to those found for recombinant mammalian TDOs and bacterial TDOs isolated many decades later [37-43], and they suggested a similarity with the by then well-known ferrous oxy hemoglobin system. A series of papers from Feigelson going back as far as 1961 also demonstrated very fluently that the activity of TDO was dependent on heme (see for example [20, 21, 44-47]). By the late 1970s, the role of heme had finally become "mainstream" in the IDO literature as well [29-34].

The suggestion $[22,48]$ that copper was involved in TDO catalysis turned out not to be correct $[49,50]$, but nonetheless generated heated debate.

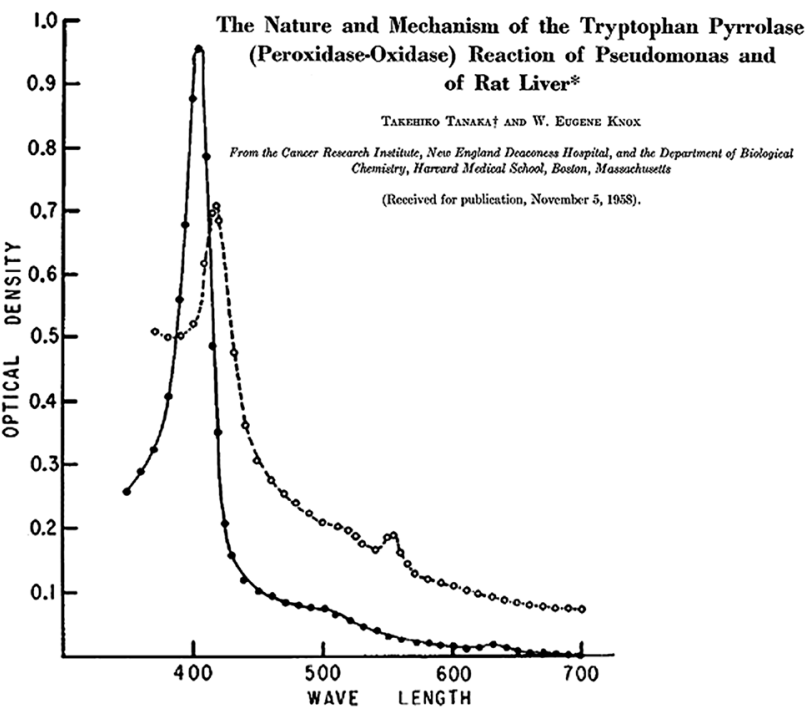

Fig. 4 An early UV-visible spectrum of TDO [16], showing a Soret absorbance at around $405 \mathrm{~nm}$ (note the nomenclature for the name of the enzyme). Reproduced with permission from The American Society for Biochemistry and Molecular Biology

\section{The 1980s onwards}

In the 10 years or from 1980, after the extensive work that had been done previously (as summarised above), a large volume of spectroscopy and kinetic work appeared on both IDO and TDO. This has been comprehensively summarised in an outstanding review by Sono and Dawson in 1996 [18] and will not be rehearsed here again. But an analysis of the literature, Fig. 5, shows that there was a lull in publication activity around the late 1980s and early 1990s. The field stalled to some extent, waiting for the development of suitable systems for expression of IDO and TDO in E. coli. An early report [37] of expression of rat TDO in E. coli stood out and led the way as it preceded, by some margin, the publication of numerous other expression systems for TDO/IDO in mammalian [38-40, 51-60], bacterial [61-63], insect [64-66], fungal [67, 68], yeast [67] and other [69] systems.

\section{A new dawn from 2000: arise again}

The Dawson review was very timely, because it included a focused but detailed summary of all of the previous IDO and TDO work. With expression systems emerging soon afterwards (see above), the review set the scene for a resurgence in interest in these enzymes over the next two decades, Fig. 5. Mauk has referred to this as a "renaissance" [70]. Much of the new work in the last few years has been motivated by the search for IDO inhibitors relevant to therapeutic application in cancer [71-73]. 


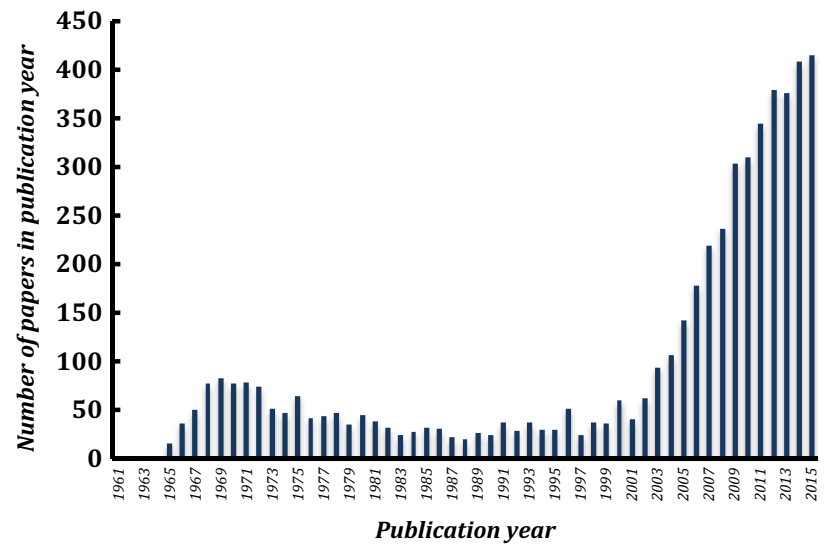

Fig. 5 An analysis from Web of Science showing the total number of literature citations in each year when searching by title in Scopus for indoleamine 2,3-dioxygenase or tryptophan 2,3-dioxygenase, going back to 1960

\section{Structure}

In terms of functional analyses, there have been some substantial developments since 2000 (see also previous reviews [74-76]). Of special note is the landmark human IDO structure from Sugimoto and Shiro [52], which gave the first glimpse of the highly hydrophobic IDO active site in complex with the inhibitor 4-phenylimidazole bound to the heme; other structures in complex with related inhibitors have recently appeared $[77,78]$ and form an important structural framework for structure-based drug design in the future.

The structure of the $X$. campestris TDO in complex with tryptophan [61], and other TDO structures have also been important $[62,66]$. The structure of human TDO in the apo form (i.e. without heme bound) has also been reported [79]. There are no structures for inhibitor-bound TDOs, with structure-based virtual screening providing the best information so far [80]. It has been suggested from spectroscopic work that the heme sites in (tetrameric) TDO may not be equivalent [81]. The recent structure of human TDO in complex with both $\mathrm{O}_{2}$ and L-Trp [82] is another step forward, and allows the first reliable visualisation of the binding orientation in the ternary complex.

There is evidence, at least in IDO, that the active site and other regions of protein structure that are not visible in the X-ray maps are conformationally mobile and that this might affect reactivity [83]; similar flexibility is known to be important in the $\mathrm{P}^{4} 50_{\text {cam }}$ system (see for example [84-86]).

\section{Mechanism}

Techniques other than crystallography have been needed to make progress on mechanism, and there is much work to do yet before the mechanism is fully clarified. Early proposals for the mechanism of NFK formation [87] have been substantially revised in recent years. The generational echoes have resonated loudly, as some of the newer ideas on mechanism [88] were derived from mass spectrometry experiments (as in the early days [6]).

Spectroscopy and kinetics, at one time the poor relations compared to the mighty crystallography, are now playing a leading role again just as they did in the 1980s (including recently on indoleamine 2,3-dioxygenase 2 (IDO-2) [89]). In terms of mechanism, there seems to be a consensus emerging that the mechanism outlined in Fig. 6 is reasonable, but things are far from being conclusively established and, bearing in mind the early mechanistic red herrings in this area [87], caution is still needed. Computational approaches have proved very useful in elucidating the mechanism [90-93].

Early proposals [87] for tryptophan oxidation suggested a base-catalysed abstraction mechanism and no change in oxidation state of the metal, but several groups had independently reported $[42,88,94]$ that the $1-\mathrm{Me}-$ L-Trp analogue was also reactive, and it was noted [95] that this is not consistent with a base-catalysed abstraction mechanism. Mutational data where the presumed active site base (histidine) had been removed were also not consistent with base-catalysed abstraction [96]. Two other mechanisms, Fig. 6, have been put forward [88, 90, 91, 97], but there is little in the way of firm evidence for either. Electrophilic addition from the ferrous oxy species, Fig. 6, is one possibility: recent evidence in TDO [98] (using modified hemes that were first used more than 30 years ago [99]) supports this. We have noted [74, 75] that oxygen may not be an especially good electrophile if it is bound to the heme as a ferric superoxide species, and there is spectroscopic evidence for a ferric superoxide species [97] from Raman's work. An alternative suggestion [97] is radical addition from the ferric superoxide, Fig. 6 (bottom). Both pathways lead to formation of a ferryl $\left(\mathrm{Fe}^{\mathrm{IV}}\right)$ species. There is mass spectrometry evidence for epoxide formation [100], but later intermediates in the mechanism are not clarified. Addition of oxygen across either the $\mathrm{C}^{2}$ or the $\mathrm{C}^{3}$ position of the substrate is possible for both the radical and electrophilic mechanisms, and at present this is a moot point. Both possibilities have been suggested [82, 88, 90, 91, 93, 97].

A real step forward was made using resonance Raman [97, 101] to identify a ferryl (Compound II) intermediate in the IDO mechanism. The same Compound II species has recently been identified kinetically and is also observed during oxidation of 1-methyl-L-Trp and a number of other substrate analogues [102], providing strong evidence that IDO uses the same mechanism for oxidation of tryptophan as it does for oxidation of other substrate 


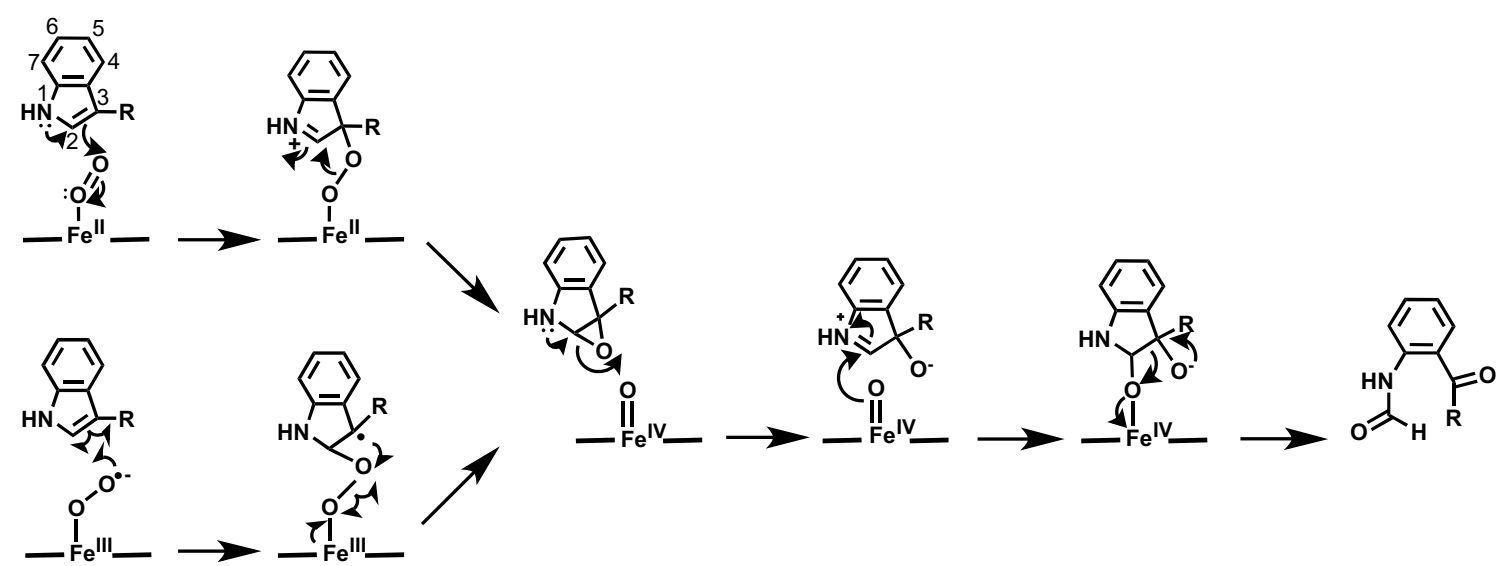

Fig. 6 A mechanism for tryptophan oxidation, consistent with all of the recent observations. Electrophilic addition (top) and radical addition (bottom) are possible. See text for details. Recent struc-

analogues. We have argued $[74,75,103]$ that since the process of oxygen activation in most heme enzymes (e.g. $\mathrm{P} 450$ s, peroxidases, etc.) is also achieved through formation of highly oxidised iron intermediates, this brings the dioxygenases into line with the oxidative mechanisms used in other heme enzymes, as illustrated schematically in Fig. 7. One difference in the dioxygenases is that continuous re-reduction of an oxidised ferryl heme (through an associated reductase) is not required, because all of the available evidence indicates that the dioxygenases only require a single, initiating reduction of ferric heme. The reader is referred to previous reviews $[74,75,103]$ for a fuller discussion.

\section{Substrate binding and catalysis}

It had been noted from very early on $[17,104]$ that the rate of tryptophan turnover in IDO decreases at high concentrations of substrate. This was originally proposed [104] to be a consequence of substrate binding to the ferric form of the enzyme, but this is not consistent with the known [51, 105] increase in reduction potential on substrate binding and has tural information [82] indicates that NFK is bound to the iron in the enzyme-product complex

therefore been questioned [106]. Some evidence suggests that the sequence of binding of $\mathrm{O}_{2}$ and the substrate at high and low substrate concentrations is important [106-108], possibly linked to changes in the reduction potential on substrate binding [106]. Others have suggested [94] that there is a second (inhibitory) binding site in IDO and that this is the origin of the inhibition-this is also plausible and there is evidence for more than one binding site (or at least multiple binding conformations) [61, 109-112], including in a recent structure for human TDO where a second L-Trp binding site (referred to as an exo site) has been clearly observed at $>40 \AA$ from the active site [82].

\section{What goes around comes around: the lasting contribution of Osamu Hayaishi}

Heme dioxygenases have floated into fashion, out of it, and back in again. The early contributions that Hayaishi made to the dioxygenase field are a lasting legacy that form a framework of reference to this day and will serve us all well as the field moves to the future. 


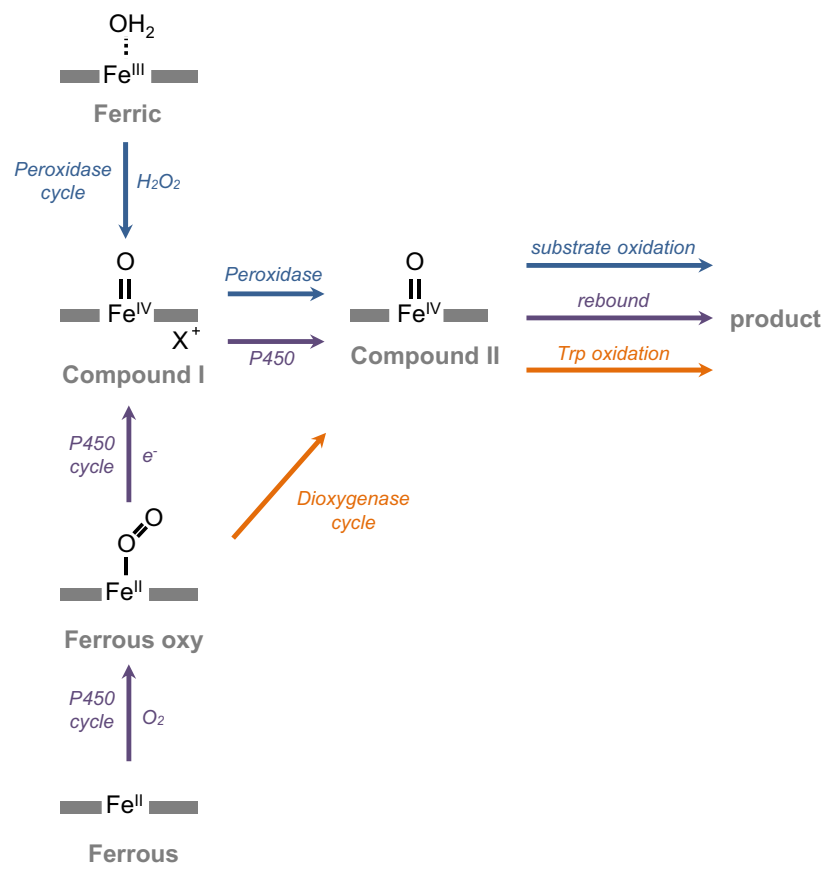

Fig. 7 A comparison of mechanisms of oxygen activation in different heme enzymes. The well-known peroxidase mechanism (blue arrows) goes via ferric heme directly to Compound I and then to Compound II by one electron oxidation of substrate [114]. The P450s (purple arrows) use the same Compound I species but they access it through the ferrous oxy species by one electron reduction, and by rebound mechanisms access the same Compound II species [115, 116]. The identification [97, 101, 102] of a Compound II species in IDO (which accumulates in the steady state) aligns the dioxygenase mechanism (orange arrows) with these established patterns of reactivity in other heme systems. It has been assumed that IDO and TDO react by the same mechanism, but Compound II in TDO has never been detected in the steady state. There is evidence that the absence of Compound II in the steady state in TDO might be due to a change in the rate-limiting step in TDO compared to IDO, such that Compound II does not accumulate [117]. Note that there is also evidence [118] that IDO can exhibit indole peroxygenase activity (i.e. a peroxide-dependent insertion of oxygen into indole), similar to the wellknown peroxide shunt of the P450s

Acknowledgements ER acknowledges Dr. J. Basran (University of Leicester), Dr. I. Rowlands (University of Leicester Library), and Prof. Almira Correia for helpful discussions.

Open Access This article is distributed under the terms of the Creative Commons Attribution 4.0 International License (http://creativecommons.org/licenses/by/4.0/), which permits unrestricted use, distribution, and reproduction in any medium, provided you give appropriate credit to the original author(s) and the source, provide a link to the Creative Commons license, and indicate if changes were made.

\section{References}

1. (2016) Revealing the impact of oxygen on molecular biology: the work of Howard Mason. J Biol Chem 291(18):9851-9852. doi:10.1074/jbc.O116.000002
2. Hayaishi O (2008) From oxygenase to sleep. J Biol Chem 283:19165-19175

3. Kresge N, Simoni RD, Hill RL (2005) Pioneering the field of oxygenases through the study of tryptophan metabolism: the work of Osamu Hayaishi (Reprinted). J Biol Chem 280

4. Mason HS, Fowlks WL, Peterson E (1955) Oxygen transfer and electron transport by the phenolase complex. J Am Chem Soc 77:2914-2915

5. Mason HS (1957) Mechanisms of oxygen metabolism. Science $125: 1185-1188$

6. Hayaishi O, Katagiri M, Rothberg S (1955) Mechanism of the pyrocatechelase reaction. J Am Chem Soc 77:5450-5451

7. Hayaishi O, Katagiri M, Rothberg S (1957) Studies on oxygenases; pyrocatechase. J Biol Chem 229:905-920

8. Hayaishi O, Rothberg S, Mehler AH (1956) Abstracts, 130th ACS meeting, Atlantic City. 53C

9. Kotake Y, Iwao J, Kujokawa M, Shichiri G, Ichihara K, Otani S, Tsujimoto J, Sakata H (1931) Z Physiol Chem 195:139-192

10. Kotake Y, Masayama I (1936) The Intermediary metabolism of tryptophan. XVIII. The mechanism of formation of kynurenine from tryptophan. Z Z Physiol Chem 243:237-244

11. Hayaishi O, Rothberg S, Mehler AH, Saito Y (1957) Studies on oxygenases; enzymatic formation of kynurenine from tryptophan. J Biol Chem 229:889-896

12. Rothberg S, Hayaishi O (1957) Studies on oxygenases; enzymatic oxidation of imidazoleacetic acid. J Biol Chem 229:897-903

13. Saito Y, Hayaishi O, Rothberg S (1957) Studies on oxygenases; enzymatic formation of 3-hydroxy-L-kynurenine from L-kynurenine. J Biol Chem 229:921-934

14. Dalgliesh CE, Knox WE, Neuberger A (1951) Intermediary metabolism of tryptophan. Nature 168:20-22

15. Knox WE, Mehler AH (1950) The conversion of tryptophan to kynurenine in liver. I. The coupled tryptophan peroxidase-oxidase system forming formylkynurenine. J Biol Chem 187:419-430

16. Tanaka T, Knox WE (1959) The nature and mechanism of the tryptophan pyrrolase (peroxidase-oxidase) reaction of Pseudomonas and of rat liver. J Biol Chem 234:1162-1170

17. Yamamoto S, Hayaishi O (1967) Tryptophan pyrrolase of rabbit intestine. D- and L-tryptophan-cleaving enzyme or enzymes. J Biol Chem 242:5260-5266

18. Sono M, Roach MP, Coulter ED, Dawson JH (1996) Heme-containing oxygenases. Chem Rev 96:2841-2888

19. Hayaishi O, Stanier RY (1951) The bacterial oxidation of tryptophan. III. Enzymatic activities of cell-free extracts from bacteria employing the aromatic pathway. J Bacteriol 62:691-709

20. Maeno H, Feigelson P (1967) Spectral studies on the catalytic mechanism and activation of Pseudomonas tryptophan oxygenase (tryptophan pyrrolase). J Biol Chem 242:596-601

21. Brady FO, Forman HJ, Feigelso P (1971) Role of superoxide and hydroperoxide in reductive activation of tryptophan-2,3-dioxygenase. J Biol Chem 246:7119

22. Brady FO (1975) Tryptophan 2,3-dioxygenase: a review of the roles of the heme and copper cofactors in catalysis. Bioinorg Chem 5:167-182

23. Ishimura Y, Nozaki M, Hayaishi O (1970) Oxygenated form of L-tryptophan 2,3-dioxygenase as reaction intermediate. J Biol Chem 245:3593

24. Hirata F, Hayaishi O, Tokuyama T, Seno S (1974) In vitro and in vivo formation of two new metabolites of melatonin. J Biol Chem 249:1311-1313

25. Hayaishi $O$ (1975) Indoleamine 2,3-dioxygenase a new vista in tryptophan-metabolism. Acta Vitaminol Enzymol 29:17-20

26. Hayaishi O, Hirata F, Fujiwara M, Senoh S, Tokuyama T (1975) Indoleamine 2,3-dioxygenase. 2. Biological function. Acta Vitaminol Enzymol 29:291-293 
27. Hirata F, Hayaishi O (1975) Studies on indoleamine 2,3-dioxygenase. 1. Superoxide anion as substrate. J Biol Chem 250:5960-5966

28. Hirata F, Nomiyama S, Hayaishi O (1975) Indoleamine 2,3-dioxygenase. 1. Catalytic and molecular-properties. Acta Vitaminol Enzymol 29:288-290

29. Hirata F, Ohnishi T, Hayaishi O (1977) Indoleamine 2,3-dioxygenase. characterization and properties of enzyme O-2-complex. J Biol Chem 252:4637-4642

30. Ohnishi T, Hirata F, Hayaishi O (1977) Indoleamine 2,3-dioxygenase-potassium superoxide as substrate. J Biol Chem 252:4643-4647

31. Fujiwara M, Shibata M, Watanabe Y, Nukiwa T, Hirata F, Mizuno N, Hayaishi O (1978) Indoleamine 2,3-dioxygenase-formation of L-kynurenine from L-tryptophan in cultured rabbit pineal-gland. J Biol Chem 253:6081-6085

32. Shimizu T, Nomiyama S, Hirata F, Hayaishi O (1978) Indoleamine 2,3-dioxygenase-purification and some properties. J Biol Chem 253:4700-4706

33. Taniguchi T, Sono M, Hirata F, Hayaishi O, Tamura M, Hayashi $\mathrm{K}$, lizuka T, Ishimura Y (1979) Indoleamine 2,3-dioxygenasekinetic studies on the binding of superoxide anion and molecular-oxygen to enzyme. J Biol Chem 254:3288-3294

34. Hayaishi O, Hirata F, Ohnishi T, Henry JP, Rosenthal I, Katoh A (1977) Indoleamine 2,3-dioxygenase-incorporation of (02)-0-18- and (02)-0-18 into reaction-products. J Biol Chem 252:3548-3550

35. Opitz CA, Litzenburger UM, Sahm F, Ott M, Tritschler I, Trump S, Schumacher T, Jestaedt L, Schrenk D, Weller M, Jugold M, Guillemin GJ, Miller CL, Lutz C, Radlwimmer B, Lehmann I, von Deimling A, Wick W, Platten M (2011) An endogenous tumour-promoting ligand of the human aryl hydrocarbon receptor. Nature 478:197-203

36. Knox WE (1952) Fed Proc 11:240

37. Ren S, Liu H, Licad E, Correia MA (1996) Expression of rat liver tryptophan 2,3-dioxygenase in Escherichia coli: structural and functional characterization of the purified enzyme. Arch Biochem Biophys 333:96-102

38. Basran J, Rafice SA, Chauhan N, Efimov I, Cheesman MR, Ghamsari L, Raven EL (2008) A kinetic, spectroscopic, and redox study of human tryptophan 2,3-dioxygenase. Biochemistry 47:4752-4760

39. Batabyal D, Yeh SR (2007) Human tryptophan dioxygenase: a comparison to indoleamine 2,3-dioxygenase. J Am Chem Soc 129:15690-15701

40. Fukumura E, Sugimoto H, Misumi Y, Ogura T, Shiro Y (2009) Cooperative binding of 1-Trp to human tryptophan 2,3-dioxygenase: resonance Raman spectroscopic analysis. J Biochem Tokyo 145:505-515

41. Fu R, Gupta R, Geng J, Dornevil K, Wang S, Zhang Y, Hendrich MP, Liu A (2011) Enzyme reactivation by hydrogen peroxide in heme-based tryptophan dioxygenase. J Biol Chem 286:26541-26554

42. Geng J, Dornevil K, Liu A (2012) Chemical rescue of the distal histidine mutants of tryptophan 2,3-dioxygenase. J Am Chem Soc 134:12209-12218

43. Rosell FI, Kuo HH, Mauk AG (2011) NADH oxidase activity of indoleamine 2,3-dioxygenase. J Biol Chem 286:29273-29283

44. Feigelson P, Greengard O (1961) A microsomal iron-porphyrin activator of rat liver tryptophan pyrrolase. J Biol Chem 236:153-157

45. Greengard O, Feigelson P (1961) The activation and induction of rat liver tryptophan pyrrolase in vivo by its substrate. J Biol Chem 236:158-161

46. Feigelson P, Greengard O (1962) Regulation of liver tryptophan pyrrolase activity. J Biol Chem 237:1908-1913
47. Poillon WN, Maeno H, Koike K, Feigelson P (1969) Tryptophan oxygenase of Pseudomonas acidovorans. Purification, composition, and subunit structure. J Biol Chem 244:3447-3456

48. Brady FO, Monaco ME, Forman HJ, Schutz G, Feigelson P (1972) On the role of copper in activation of and catalysis by tryptophan-2,3-dioxygenase. J Biol Chem 247:7915-7922

49. Ishimura Y, Hayaishi O (1973) Noninvolvement of copper in L-tryptophan 2,3-dioxygenase reaction. J Biol Chem 248:8610-8612

50. Ishimura Y, Makino R, Ueno R, Sakaguchi K, Brady FO, Feigelson P, Aisen P, Hayaishi O (1980) Copper is not essential for the catalytic activity of L-tryptophan 2,3-dioxygenase. J Biol Chem 255:3835-3837

51. Papadopoulou ND, Mewies M, McLean KJ, Seward HE, Svistunenko DA, Munro AW, Raven EL (2005) Redox and spectroscopic properties of human indoleamine 2,3-dioxygenase and a His303Ala variant: implications for catalysis. Biochemistry 44:14318-14328

52. Sugimoto H, Oda S, Otsuki T, Hino T, Yoshida T, Shiro Y (2006) Crystal structure of human indoleamine 2,3-dioxygenase: catalytic mechanism of $\mathrm{O}_{2}$ incorporation by a heme-containing dioxygenase. Proc Natl Acad Sci USA 103:2611-2616

53. Vottero E, Mitchell DA, Page MJ, MacGillivray RTA, Sadowski IJ, Roberge M, Mauk AG (2006) Cytochrome b5 is a major reductant in vivo of human indoleamine 2,3-dioxygenase expressed in yeast. FEBS Lett 580:2265-2268

54. Littlejohn TK, Takikawa O, Skylas D, Jamie JF, Walker MJ, Truscott RJW (2000) Expression and purification of recombinant human indoleamine 2,3-dioxygenase. Protein Expres Purif 19:22-29

55. Austin C, Astelbauer F, Kosim-Satyaputra P, Ball H, Willows R, Jamie J, Hunt N (2009) Mouse and human indoleamine 2,3-dioxygenase display some distinct biochemical and structural properties. Amino Acids 36:99-106

56. Dick R, Murray BP, Reid MJ, Correia MA (2001) Structurefunction relationships of rat hepatic tryptophan 2,3-dioxygenase: identification of the putative heme-ligating histidine residues. Arch Biochem Biophys 392:71-78

57. Manandhar SP, Shimada H, Nagano S, Egawa T, Ishimura Y (2002) Subunit structure of recombinant rat liver L-tryptophan 2,3-dioxygenase. Int Congr Ser 1233:161-169

58. Austin CJ, Mizdrak J, Matin A, Sirijovski N, Kosim-Satyaputra P, Willows RD, Roberts TH, Truscott RJ, Polekhina G, Parker MW, Jamie JF (2004) Optimised expression and purification of recombinant human indoleamine 2,3-dioxygenase. Protein Expr Purif 37:392-398

59. Austin CJ, Kosim-Satyaputra P, Smith JR, Willows RD, Jamie JF (2013) Mutation of cysteine residues alters the heme-binding pocket of indoleamine 2,3-dioxygenase-1. Biochem Biophys Res Commun 436:595-600

60. Austin CJ, Mailu BM, Maghzal GJ, Sanchez-Perez A, Rahlfs S, Zocher K, Yuasa HJ, Arthur JW, Becker K, Stocker R, Hunt $\mathrm{NH}$, Ball HJ (2010) Biochemical characteristics and inhibitor selectivity of mouse indoleamine 2,3-dioxygenase-2. Amino Acids 39:565-578

61. Forouhar F, Anderson JL, Mowat CG, Vorobiev SM, Hussain A, Abashidze M, Bruckmann C, Thackray SJ, Seetharaman J, Tucker T, Xiao R, Ma LC, Zhao L, Acton TB, Montelione GT, Chapman SK, Tong L (2007) Molecular insights into substrate recognition and catalysis by tryptophan 2,3-dioxygenase. Proc Natl Acad Sci USA 104:473-478

62. Zhang Y, Kang SA, Mukherjee T, Bale S, Crane BR, Begley TP, Ealick SE (2007) Crystal structure and mechanism of tryptophan 2,3-dioxygenase, a heme enzyme involved in tryptophan catabolism and in quinolinate biosynthesis. Biochemistry 46:145-155 
63. Yuasa HJ, Ushigoe A, Ball HJ (2011) Molecular evolution of bacterial indoleamine 2,3-dioxygenase. Gene 485:22-31

64. Li JS, Han Q, Fang JM, Rizzi M, James AA, Li JY (2007) Biochemical mechanisms leading to tryptophan 2,3-dioxygenase activation. Arch Insect Biochem 64:74-87

65. Paglino A, Lombardo F, Arca B, Rizzi M, Rossi F (2008) Purification and biochemical characterization of a recombinant Anopheles gambiae tryptophan 2,3-dioxygenase expressed in Escherichia coli. Insect Biochem Mol Biol 38:871-876

66. Huang W, Gong Z, Li J, Ding J (2013) Crystal structure of Drosophila melanogaster tryptophan 2,3-dioxygenase reveals insights into substrate recognition and catalytic mechanism. J Struct Biol 181:291-299

67. Yuasa HJ, Ball HJ (2011) Molecular evolution and characterization of fungal indoleamine 2,3-dioxygenases. J Mol Evol 72:160-168

68. Yuasa HJ, Ball HJ (2012) The evolution of three types of indoleamine 2,3 dioxygenases in fungi with distinct molecular and biochemical characteristics. Gene 504:64-74

69. Hu XL, Bao ZM, Hu JJ, Shao MY, Zhang LL, Bi K, Zhan AB, Huang XT (2006) Cloning and characterization of tryptophan 2,3-dioxygenase gene of Zhikong scallop Chlamys farreri (Jones and Preston 1904). Aquac Res 37:1187-1194

70. Mauk AG (2011) The renaissance of indoleamine 2,3-dioxygenase. Plenary lecture, ICBIC meeting, Vancouver

71. Uyttenhove C, Pilotte L, Theate I, Stroobant V, Colau D, Parmentier N, Boon T, Van den Eynde BJ (2003) Evidence for a tumoral immune resistance mechanism based on tryptophan degradation by indoleamine 2,3-dioxygenase. Nat Med 9:1269-1274

72. Lob S, Konigsrainer A, Rammensee HG, Opelz G, Terness P (2009) Inhibitors of indoleamine-2,3-dioxygenase for cancer therapy: can we see the wood for the trees? Nat Rev Cancer 9:445-452

73. Chen W (2011) IDO: more than an enzyme. Nat Immunol 12:809-811

74. Efimov I, Basran J, Thackray SJ, Handa S, Mowat CG, Raven EL (2011) Structure and reaction mechanism in the heme dioxygenases. Biochemistry 50:2717-2724

75. Millett ES, Efimov I, Basran J, Handa S, Mowat CG, Raven EL (2012) Heme-containing dioxygenases involved in tryptophan oxidation. Curr Opin Chem Biol 16:60-66

76. Geng J, Liu A (2014) Heme-dependent dioxygenases in tryptophan oxidation. Arch Biochem Biophys 544:18-26

77. Peng YH, Ueng SH, Tseng CT, Hung MS, Song JS, Wu JS, Liao FY, Fan YS, Wu MH, Hsiao WC, Hsueh CC, Lin SY, Cheng CY, Tu CH, Lee LC, Cheng MF, Shia KS, Shih C, Wu SY (2016) Important hydrogen bond networks in indoleamine 2,3-dioxygenase 1 (IDO1) inhibitor design revealed by crystal structures of imidazoleisoindole derivatives with IDO1. J Med Chem 59:282-293

78. Tojo S, Kohno T, Tanaka T, Kamioka S, Ota Y, Ishii T, Kamimoto K, Asano S, Isobe Y (2014) Crystal structures and structure-activity relationships of imidazothiazole derivatives as IDO1 inhibitors. ACS Med Chem Lett 5:1119-1123

79. Meng B, Wu D, Gu J, Ouyang S, Ding W, Liu ZJ (2014) Structural and functional analyses of human tryptophan 2,3-dioxygenase. Proteins 82:3210-3216

80. Wu JS, Lin SY, Liao FY, Hsiao WC, Lee LC, Peng YH, Hsieh $\mathrm{CL}$, Wu MH, Song JS, Yueh A, Chen CH, Yeh SH, Liu CY, Lin SY, Yeh TK, Hsu JT, Shih C, Ueng SH, Hung MS, Wu SY (2015) Identification of substituted naphthotriazolediones as novel tryptophan 2,3-dioxygenase (TDO) inhibitors through structure-based virtual screening. J Med Chem 58:7807-7819

81. Gupta R, Fu R, Liu A, Hendrich MP (2010) EPR and Mossbauer spectroscopy show inequivalent hemes in tryptophan dioxygenase. J Am Chem Soc 132:1098-1109
82. Lewis-Ballester A, Forouhar F, Kim S-M, Lew S, Wang Y, Karkashon S, Seetharaman J, Batabyal D, Chiang B-Y, Hussain M, Correia MA, Yeh S-R, Tong L (2016) Molecular basis for catalysis and substrate-mediated cellular stabilization of human tryptophan 2,3-dioxygenase. Sci Rep 6:35169. doi:10.1038/srep35169.

83. Alvarez L, Lewis-Ballester A, Roitberg A, Estrin DA, Yeh SR, Marti MA, Capece L (2016) Structural study of a flexible active site loop in human indoleamine 2,3-dioxygenase and its functional implications. Biochemistry 55:2785-2793

84. Liou SH, Mahomed M, Lee YT, Goodin DB (2016) Effector roles of putidaredoxin on cytochrome P450cam conformational states. J Am Chem Soc 138:10163-10172

85. Lee YT, Glazer EC, Wilson RF, Stout CD, Goodin DB (2011) Three clusters of conformational states in P450cam reveal a multistep pathway for closing of the substrate access channel. Biochemistry 50:693-703

86. Hollingsworth SA, Batabyal D, Nguyen BD, Poulos TL (2016) Conformational selectivity in cytochrome $\mathrm{P} 450$ redox partner interactions. Proc Natl Acad Sci USA 113:8723-8728

87. Hamilton GA (1969) Mechanisms of two- and four-electron oxidations catalyzed by some metalloenzymes. Adv Enzymol Relat Areas Mol Biol 32:55-96

88. Chauhan N, Thackray SJ, Rafice SA, Eaton G, Lee M, Efimov I, Basran J, Jenkins PR, Mowat CG, Chapman SK, Raven EL (2009) Reassessment of the reaction mechanism in the heme dioxygenases. J Am Chem Soc 131:4186

89. Aitken JB, Austin CJ, Hunt NH, Ball HJ, Lay PA (2014) The Fe-heme structure of met-indoleamine 2,3-dioxygenase-2 determined by X-ray absorption fine structure. Biochem Biophys Res Commun 450:25-29

90. Chung LW, Li X, Sugimoto H, Shiro Y, Morokuma K (2008) Density functional theory study on a missing piece in understanding of heme chemistry: the reaction mechanism for indoleamine 2,3-dioxygenase and tryptophan 2,3-dioxygenase. J Am Chem Soc 130:12299-12309

91. Chung LW, Li X, Sugimoto H, Shiro Y, Morokuma K (2010) ONIOM study on a missing piece in our understanding of heme chemistry: bacterial tryptophan 2,3-dioxygenase with dual oxidants. J Am Chem Soc 132:11993-12005

92. Capece L, Lewis-Ballester A, Batabyal D, Di Russo N, Yeh SR, Estrin DA, Marti MA (2010) The first step of the dioxygenation reaction carried out by tryptophan dioxygenase and indoleamine 2,3-dioxygenase as revealed by quantum mechanical $/ \mathrm{molec}$ ular mechanical studies. J Biol Inorg Chem 15:811-823

93. Capece L, Lewis-Ballester A, Yeh SR, Estrin DA, Marti MA (2012) Complete reaction mechanism of indoleamine 2,3-dioxygenase as revealed by QM/MM simulations. J Phys Chem B 116:1401-1413

94. Lu C, Lin Y, Yeh SR (2009) Inhibitory substrate binding site of human indoleamine 2,3-dioxygenase. J Am Chem Soc 131:12866-12867

95. Chauhan N, Thackray SJ, Rafice SA, Eaton G, Lee M, Efimov I, Basran J, Jenkins PR, Mowat CG, Chapman SK, Raven EL (2009) Reassessment of the reaction mechanism in the heme dioxygenases. J Am Chem Soc 131:4186-4187

96. Thackray SJ, Bruckmann C, Anderson JL, Campbell LP, Xiao R, Zhao L, Mowat CG, Forouhar F, Tong L, Chapman SK (2008) Histidine 55 of tryptophan 2,3-dioxygenase is not an active site base but regulates catalysis by controlling substrate binding. Biochemistry 47:10677-10684

97. Lewis-Ballester A, Batabyal D, Egawa T, Lu C, Lin Y, Marti MA, Capece L, Estrin DA, Yeh SR (2009) Evidence for a ferryl intermediate in a heme-based dioxygenase. Proc Natl Acad Sci USA 106:17371-17376

98. Makino R, Obayashi E, Hori H, Iizuka T, Mashima K, Shiro Y, Ishimura Y (2015) Initial O(2) insertion step of the tryptophan 
dioxygenase reaction proposed by a heme-modification study. Biochemistry 54:3604-3616

99. Makino R, Iizuka T, Sakaguchi K, Ishimura Y (1983) Effects of substitution on the activity of heme-containing oxygenases. Oxygenases and oxygen metabolism (a symposium in honor of Osamu Hayaishi). Academic Press, New York, pp 468-477

100. Basran J, Efimov I, Chauhan N, Thackray SJ, Krupa JL, Eaton G, Griffith GA, Mowat CG, Handa S, Raven EL (2011) The mechanism of formation of $N$-formylkynurenine by heme dioxygenases. J Am Chem Soc 133:16251-16257

101. Yanagisawa S, Yotsuya K, Hashiwaki Y, Horitani M, Sugimoto H, Shiro Y, Appelman EH, Ogura T (2010) Identification of the $\mathrm{Fe}-\mathrm{O}_{2}$ and the $\mathrm{Fe}=\mathrm{O}$ heme species for indoleamine 2,3-dioxygenase during catalytic turnover. Chem Lett 39:36-37

102. Booth ES, Basran J, Lee M, Handa S, Raven EL (2015) Substrate oxidation by indoleamine 2,3-dioxygenase. J Biol Chem 290:30924-30930

103. Efimov I, Basran J, Thackray SJ, Handa S, Mowat CG, Raven EL (2012) Heme-Containing Dioxygenases. In: van Eldik R (ed) Advances in inorganic chemistry. Academic Press, London, pp 34-51

104. Sono M, Taniguchi T, Watanabe Y, Hayaishi O (1980) Indoleamine 2,3-dioxygenase-equilibrium studies of the tryptophan binding to the ferric, ferrous, and co-bound enzymes. $\mathbf{J}$ Biol Chem 255:1339-1345

105. Chauhan N, Basran J, Efimov I, Svistunenko DA, Seward HE, Moody PC, Raven EL (2008) The role of serine 167 in human indoleamine 2,3-dioxygenase: a comparison with tryptophan 2,3-dioxygenase. Biochemistry 47:4761-4769

106. Efimov I, Basran J, Sun X, Chauhan N, Chapman SK, Mowat CG, Raven EL (2012) The mechanism of substrate inhibition in human indoleamine 2,3-dioxygenase. J Am Chem Soc 134:3034-3041

107. Kolawole AO, Hixon BP, Dameron LS, Chrisman IM, Smirnov VV (2015) Catalytic activity of human indoleamine 2,3-dioxygenase (hIDO1) at low oxygen. Arch Biochem Biophys 570:47-57

108. Weber B, Nickel E, Horn M, Nienhaus K, Nienhaus GU (2014) Substrate inhibition in human indoleamine 2,3-dioxygenase. J Phys Chem Lett 5:756-761

109. Macchiarulo A, Nuti R, Bellocchi D, Camaioni E, Pellicciari $R$ (2007) Molecular docking and spatial coarse graining simulations as tools to investigate substrate recognition, enhancer binding and conformational transitions in indoleamine-2,3-dioxygenase (IDO). Biochim Biophys Acta 1774:1058-1068

110. Capece L, Arrar M, Roitberg AE, Yeh SR, Marti MA, Estrin DA (2010) Substrate stereo-specificity in tryptophan dioxygenase and indoleamine 2,3-dioxygenase. Proteins 78:2961-2972

111. Nickel E, Nienhaus K, Lu C, Yeh SR, Nienhaus GU (2009) Ligand and substrate migration in human indoleamine 2,3-dioxygenase. J Biol Chem 284:31548-31554

112. Yuasa HJ (2016) High L-Trp affinity of indoleamine 2,3-dioxygenase 1 is attributed to two residues located in the distal heme pocket. FEBS Lett. doi:10.1111/febs.13834

113. (2016) Nature Digest (Japanese edition) 13:26-31

114. Raven E, Dunford HB (2015) Heme peroxidases. Royal Society of Chemistry, Cambridge

115. Ortiz de Montellano PR (1995) Cytochrome P450: structure, mechanism, and biochemistry. Plenum Press, New York

116. Ortiz de Montellano PR (2005) Cytochrome P450: structure, mechanism, and biochemistry, 3rd edn. Kluwer Academic/Plenum Publishers, Dordrecht

117. Basran J, Booth ES, Lee M, Handa S, Raven EL (2016) Analysis of reaction intermediates in Tryptophan 2,3-Dioxygenase: a comparison with Indoleamine 2,3-Dioxygenase. Biochemistry. doi:10.1021/acs.biochem.6b01005

118. Kuo HH, Mauk AG (2012) Indole peroxygenase activity of indoleamine 2,3-dioxygenase. Proc Natl Acad Sci USA 109:13966-13971 